\title{
Embracing student experience in inclusive design education through learner-centred instruction
}

\section{Burçak Altay, Gülnur Ballice, Ebru Bengisu, Sevinç Alkan-Korkmaz \& Eda Paykoç}

To cite this article: Burçak Altay, Gülnur Ballice, Ebru Bengisu, Sevinç Alkan-Korkmaz \& Eda Paykoç (2016) Embracing student experience in inclusive design education through learnercentred instruction, International Journal of Inclusive Education, 20:11, 1123-1141, DOI: 10.1080/13603116.2016.1155662

To link to this article: https://doi.org/10.1080/13603116.2016.1155662

册 Published online: 07 Mar 2016.

Submit your article to this journal 전

LII Article views: 662

Q View related articles $\longleftarrow$

View Crossmark data [ᄌ

4 Citing articles: 1 View citing articles 준 


\title{
Embracing student experience in inclusive design education through learner-centred instruction
}

\author{
Burçak Altay $^{\mathrm{a}}$, Gülnur Ballice ${ }^{\mathrm{b}}$, Ebru Bengisu ${ }^{\mathrm{b}}$, Sevinç Alkan-Korkmaz ${ }^{\mathrm{b}}$ and Eda Paykoç \\ ${ }^{a}$ Department of Interior Architecture and Environmental Design, Bilkent University, Ankara, Turkey; ${ }^{b}$ Department of \\ Interior Architecture and Environmental Design, Yaşar University, İzmir, Turkey
}

\begin{abstract}
This paper explores the process and outcome of using learner-centred methods to develop students' empathic design abilities during an educational workshop on inclusive design. In the first section of the paper, we suggest the significance of incorporating inclusive design within the education of design disciplines. Then, we introduce a workshop on inclusive design awareness that architecture and interior design students participated, which applied various learner-centred methods. We discuss the process that incorporated project-based learning, role-playing/simulation and students' reflections and feedback on their experience. The workshop process, the student project experience and students' reflections on their learning indicate how multiple methods of learning engage students and enhance their empathic understanding so they can embrace differences and adopt a user-centred design approach. Based on the findings, we provide suggestions for similar educational events that can be applied in other disciplinary contexts.
\end{abstract}

ARTICLE HISTORY

Received 2 June 2015

Accepted 30 January 2016

\section{KEYWORDS}

Learner-centred; design

education; empathic design; inclusive education

\section{Introduction}

In the most general sense, the design professions are concerned with the change, maintenance and creation of the human-made world (Cross 1982, 2001). This world of 'artefacts' or 'things' include not only physical objects, but also functions and uses of things and the situations, or environments which they function (Jones 1992). The design professions range across disciplines such as graphic design, communication design, product design as well as those concerned with the creation of spaces - the natural and built environment - which comprise interior architecture, architecture, landscape design and urban design.

Among the range of people that designers consider in their practices, many have psychological and physiological characteristics different than the designer, such as those with variance in gender, abilities and age. In the creative design process, designers need to observe and understand people, things and their interaction in their natural settings, in order to be able to provide meaningful relationships between users and the human-made environment, which they contribute to. However, there is often a mismatch between the environment and user needs, which causes barriers to comfortable access and use. Particularly for children, the elderly and disabled people, the inaccessibility of the environment may lead to physical and social isolation. In that respect, the professionals responsible for designing the built environment should provide integrative and accessible spaces. In order for environments to be compatible for everyone, an inclusive design approach is fundamental. 
Inclusive design, a term widely used across Europe, sometimes interchangeably with design-forall, mainly denotes designing of spaces inhabited, and products used by people considering their diverse capabilities and characteristics (Morrow 2002). Inclusive design therefore embraces and accommodates the differences among people, and offers variety of solutions that accounts for these. Similarly, Universal Design, term initially coined in the USA, focuses on providing equal opportunity and access to all types of user groups as they relate to environments, products, and communications independently and naturally, without any special need of adaptation (The Center for Universal Design 1997). Universal design is characterised by the seven main principles to guide design professions, which include: equitable use, flexibility in use, perceptible information, simple and intuitive use, low physical effort, tolerance for error, size and space for approach and use.

Inclusive design considers placing users at the centre of the design process, where users are the primary stakeholders that shape and pioneer the major design decisions; rather than the designers' subjective preferences or material/technological/economic priorities. Termed initially as usercentred design, and later with human-centred design since it is more 'inclusive' going beyond mere usability, this approach is 'based on the use of techniques which communicate, interact, empathize and simulate the people involved, obtaining and understanding their needs, desires and experiences which often transcends that which people themselves have realized' (Giacomin 2014, 610). Thus, products, services and environments are naturally 'intuitive' where they can resonate with the cognitive, physical and affective attributes of all users equally. Buchanan (2001) points out that the fundamentals of such a design thinking are grounded in human rights and human dignity, embracing all aspects of ergonomic, psychological, social and cultural means. As such, inclusive design places particular emphasis on elderly users and people with disabilities, since the built environment in many situations fails to relate to their needs and expectations; physically, culturally and emotionally.

\section{Disability in the Turkish context}

In the last three decades, there has been a rising awareness of Turkish architects that their designs must cater for everyone rather than the 'average' healthy human being. The Turkish Institution of Standards accepted the TSE standard no. 9111 in 1991 which defines how buildings can be designed according to the needs of everyone. In 1997, the Directorate of the Disabled, connected to the Prime Ministry was established and new arrangements were made in the planning law. In 2005 a law relating to the disabled was passed. Accordingly, existing buildings were to be converted in a way to cater for their needs. Local governments were allowed a seven-year period in order to realise this objective. Meanwhile, The Turkish Chamber of Architects has been carrying out educational programmes since 2007 about inclusive design, to increase members' consciousness on design issues related to the disabled and the elderly (Dostoğlu, Şahin, and Taneli 2009).

Although inclusive design philosophy is slowly integrated into the professional and spheres in many aspects, difficulties remain in their implementation. Disabled people in Turkey encounter difficulties in their interactions with the built environment. According to a Turkish Statistical Institute survey conducted in $2002,12.29 \%$ of the Turkish population is disabled. Of this number, $2.58 \%$ is orthopedically, visually, verbally, auditorially or intellectually disabled, while $9.70 \%$ of that population has chronic illnesses. Sixty-eight per cent of the disabled people surveyed indicated that no environmental/design solutions have been introduced for their abilities (TSI 2014). When the daily activities of disabled people according to barrier type are assessed, the majority of hearingimpaired, sight-impaired, speech-impaired and people with mental disorder have difficulty carrying out activities independently (TSI 2002).

If a nation has between $7 \%$ and $10 \%$ of population at 65 or above years of age, it is considered as 'an aged society'. If this figure is more than $10 \%$, then that society is defined as 'very aged'. It is estimated that Turkey will have 'a very aged society' by 2023 (Başbakanlık 2005). Accordingly, people over 65 years of age in Turkey, who comprise $8 \%$ of the general population (TSI 2014), also have 
ranging abilities and experience dissatisfaction with their physical environments, both in the public context (Türel, Yiğit, and Altuğ 2007) and in their home environments (Afacan 2008). While public environments may be inaccessible due to level differences, narrow roads and other non-supportive aspects, problems within the home occur due to difficulties with reaching, bending, lifting and movement. Physical features such as inaccessible storage that are too high or too low, stairs, narrow halls and heavy furniture difficult to lift and move, restrict comfortable daily life.

Designing home environments and public spaces such as institutions, sports areas and parks according to users with diverse needs is thus a fundamental aspect of design professions. Many of the problems that occur due to user-environment incompatibility can be solved during the design phase if designers can relate to and understand all potential users' needs. This approach calls for an inclusive outlook that encompasses an empathic understanding of the user group, and establishes its foundations in education.

\section{Inclusive design education}

The problem of user inclusivity in interior and exterior spaces should be fully considered in design education. While promoting the integration of an inclusive design approach in the education of built environment professionals, Morrow (2002) introduces moral, sustainable, professional, economic and legal arguments. She suggests that as a professional, the core moral responsibility of the designer is to help establish an environment that enables rather than disables, with the acknowledgement that an environment whereby everyone can participate equally is a basic human right. Morrow (2002) discusses inclusive design education strategies, methods and applications which not only include sources of information and modules that can be utilised across courses, but also universities and institutes across UK, USA, Europe, Japan, Canada and Australia that integrate inclusive design in curriculum, within design studio instruction and/or independent courses and programmes. Similarly, Committee on the Rehabilitation and Integration of People with Disabilities within Council of Europe (2001) and the United States Department of Education (2013) suggest that inclusive/universal design principles should be incorporated within the education policies and practices of designrelated disciplines.

In Turkey, inclusive education is essential to be a part of the curriculum in design-based disciplines, which is set out by the Higher Education Council's (YÖK) Higher Education Institutions Disability Advice and Coordination Regulations. This inclusion necessitates a 'design-for-all' approach to be nationally integrated into the university curricula for urban planning, landscape design, architecture, interior design and industrial design programmes (Öztül et al. 2011). National Qualifications Framework for Higher Education in Turkey (NQF-HETR) defines the designer qualifications related to inclusive design and human-centred design in the field of Architecture and Building. Architects are required to possess sensitivity to and knowledge of natural and human-made environment, centred on human and society, working on design, planning and research methods (National Qualifications Framework for Higher Education in Turkey 2015). The design of a university campus should itself should also consider people with disabilities (Resmi Gazete 2010).

Within the scope of the Research Project ACTUS (Accessibility Network for Turkish-Greek Societies) in 2008, a survey was conducted related to 'Universal Design' and 'Inclusive Design' issues in the departments of Architecture, Urban and Regional Planning, Landscape Architecture and Interior Architecture of Turkish universities. The objective was to find out the number of courses, projects, research and other activities on universal design. Forty-five out of 65 universities responded to the survey. The results revealed that $86 \%$ of universities do not have a theoretical or an applied course related to inclusive design. Only 12 undergraduate and nine graduate courses were available on this issue. Only three departments have made their inclusive design course compulsory. When the course contents were analysed, it was seen that this issue was included only as a part of the syllabus. In design studios, the issue of inclusive design was considered as any other ordinary design factor. This was observed at a ratio of $90 \%$ in total (Mishchenko 2008). There have been cases however, 
where inclusive design strategies and methods are integrated in the curriculum of the design programme in many different levels; such as embedding it within the design studios (Afacan 2011), within the related compulsory/elective Human Factors/Ergonomics courses (Altay 2014; Altay and Demirkan 2014) and as an elective course on Universal Design (Olguntürk and Demirkan 2009).

Acknowledging the necessity of incorporating inclusive design awareness within the educational context in Turkey, one of the programme outcomes of the Department of Interior Architecture and Environmental Design of Yaşar University is associated with inclusive design. This refers the recognition and capability of using inclusive and sustainable design principles having understood the importance of human-environment relations and the health and safety of users; integrating it within the curriculum. In the department, People and Environment course is offered as a compulsory course in the second year of the Interior Architecture and Environmental Design curriculum, along with the recently introduced elective course Human Factors, again for second year students. Both of these courses cover issues of inclusive design. Concurrently, the approach is also majorly applied in the interior design studios. Focused events open to interdepartmental participation as described below is to support this approach. Accordingly, it is assumed that the lecture series and following workshop will enhance the students' knowledge and awareness on inclusive design.

\section{'Overcoming disabilities by design' event}

The Faculty of Architecture of Yaşar University a two-day event which consist of a symposium and a workshop called 'Overcoming Disabilities by Design' in December 2013. The aim of the symposium was to consider inclusivity from diverse perspectives, reaching beyond the boundaries of the university; to ensure the participation of students, colleagues from other departments, people with disabilities and advocacy associations so as to provide a comprehensive awareness and discussion about inclusive design.

The first day of the event was organised as a conference in which speakers from different backgrounds shared their knowledge. Educators, independent researchers and officials from governmental institutions and the municipality were invited as speakers. The conference drew strong interest, especially from advocacy associations, and it was well covered in the local media. Following the single-day conference, students of architecture and interior design departments participated in a whole-day workshop which supported the issues covered in the conference. The last speaker of the conference who gave general knowledge on the importance of inclusive design awareness with different examples from daily life also coordinated the workshop the following day. The workshop participants expected to attend sessions of the symposium on the first day.

The focus of this paper is on the process and outcome of the workshop. We particularly discuss the learning methodology applied, procedure and results of the workshop, followed by a study concerning students' reflections about the event.

\section{Learning methodology}

Considering the significance of inclusive design in the education of design professionals, the following question arises: What are the best ways to integrate inclusive design issues and concepts so that students are aware of and understand the subject, but are also able to apply what is learned to actual design problems? Kahu (2013) determines student engagement necessary for learning in higher education, and to achieve this, suggests integrating affective components to generate enthusiasm and interest as well as cognitive components to ensure deep learning.

The basic premise of inclusive design is to dissolve the boundaries and categories between designer and user, and between disabled and able-bodied people. In that respect, students are required to engage with how people different from themselves perceive and experience the built environment. Doing so necessitates the user to be in the centre of the design activity. Students need to step out of their roles as designers and step into roles as users (Kouprie and Visser 2009). 
With a 'feel' for the user, students can understand the built environment from the user's perspective (Postma et al. 2012). Empathic design goes beyond textbook knowledge and mere measurements and numbers; it aims to develop designers' abilities to identify with others' thoughts, emotions, understandings, expectations and hopes (McDonagh and Thomas 2010; Postma et al. 2012). This method also encourages inspirational and novel design solutions that consider individuals' specific experiences, however varied and dissimilar they might be (Dankl 2013; McGinley and Dong 2011).

When utilising learning strategies that allow for empathy between students and others, learnercentred methods (Bonwell and Sutherland 1996) offer a rich horizon because they shift the knowledge-making process from the instructor to the students. Students learn as they encounter the material at hand, re-constructing their relationship with their work during the process. Thus, students engage with real-world experiences by creating, doing and acting with their minds and bodies going beyond the mere cognitive and theoretical framework (Altay 2014; Sutherland 2011). Studentcentred learning methods have been applied across a wide range of disciplines, where the central objective is for students to address questions and arrive at their own solutions (Aditomo et al. 2013). Inquiry through the process is thus fundamental to students' learning. Within a wide range of learner-centred instruction strategies, project-based learning, role-playing/simulation and reflection can all enhance empathic design education to account for inclusivity.

\section{Project-based learning}

Project-based learning is the predominant learning method in design disciplines, where students are given a problem and they arrive at a tangible product as a final outcome, redefining, interpreting and developing the problem during the process (Aditomo et al. 2013; Lee 2009). Using project-based methods, students must develop an understanding of the user(s) to develop possible solutions, and they need to integrate these understandings during the design development process. In that respect, the possible and multiple ways for users to interact with the proposed design is students' primary concern, a method that enhances empathic design.

\section{Role-playing/simulation}

Through role-playing/simulation students engage in situations they may encounter in real life and thus carry out professional activities accordingly (Aditomo et al. 2013). Through this method, students act out real or imaginary roles and scenarios significant to the relevant discipline. Role-play is applied widely in the educational context across disciplines (Altay and Demirkan 2014; Livingston 2000; Watchorn et al. 2013). These range from active, experience-based exercises that simulate disability issues such as loss of vision and hearing, as well as other impairments (Lewis 2011); to considerations of how people of different races and/or genders may experience the environment (Livingston 2000). Such exercises attempt to challenge students' existing beliefs and assumptions about themselves and others. For the design disciplines, role-play is particularly significant, encouraging students to empathise with potential users and provide solutions accordingly. Moreover, learning through role-play has been influential in increasing students' emotional engagement, where students exhibit higher levels of participation and commitment (Heyward 2010).

\section{Reflection}

Reflection involves a student looking back at the task and his or her relationship to it, evaluating his or her own positioning with respect to what has been achieved and learned. Reflection is thus a reestablishment of one's active role within the learning process (Kreber 2001; Ryan 2013). In design disciplines, reflective practice is a natural process of the design critique, whereby the student develops his or her own project, supported by an ongoing dialogue with the instructor as they engage in a reflective conversation with the situation. Thus, 'in answer to the situations' back-talk, the designer 
reflects-in-action on the construction of a problem, the strategies of action or the model of the phenomena, which have been implicit in his moves' (Schon 1983, 79). The student continuously utilises this dialogue in further design decisions. Bulman, Lathleand, and Gobbi (2014) suggest that reflection not only promotes critical thinking skills and cognitive engagement, but also students' awareness of their feelings and emotions, leading to design solutions that make a positive difference.

Project-based learning, role-playing/simulation and reflection were all utilised in the single-day workshop following the conference.

\section{Workshop: methods, procedure and results}

The workshop called 'A 3D Experience to Increase Universal Design Awareness' encouraged students to explore the following questions through their design process:

- How does interaction occur between the spaces/products/elements that we design and people with different physical characteristics, needs, requirements and expectations?

- What type of spaces/products reveal qualities that make us more ourselves, rather than less; integrate rather than separate; enable rather than disable?

- How can we provide a different understanding of our own relationship to spaces/products through design?

Forty-seven second- to fourth-year students (39 female, eight male) from the university's Interior Architecture and Environmental Design (IAED) and Architecture Departments (ADs) attended the workshop. The distribution of participants according to their year of study and area of specialisation was as follows: Forty-two IAED (16 - 2nd, 11 - 3rd, 15 - 4th year) and five AD (4 - 4th, 1 - 1st year). Accordingly, as previously noted, while all the 26 students a $3 \mathrm{rd}$ and 4 th year IAED students had been introduced to the subject in People and Environment course that they had completed in the second year, the 16 participants from 2nd year IAED was taking the Human Factors course concurrently with the workshop. However, since there is no course about inclusive design in the curriculum of $\mathrm{AD}$, those students were exposed to the subject in their design studios.

Although the specified learning methodologies (i.e. student-centred learning, project-based learning, role-playing and reflection) are integrated in daily teaching especially within their project studios, by considering these different backgrounds of the students on inclusive design issues, the first day 'presentation sessions' was expected to have greater benefits on each participant.

Table 1 represents the tasks carried out by the students during and after the workshop.

Through an overview of the introductory Task 1, this paper briefly explains the design process (Task 2) and focuses on the experience of the products designed by the students (Task 3 ). The results of two surveys conducted with the students are also discussed within this context, as they comprise a part of the students' learning process through reflection. The first survey (Task 4) consists of student feedback on the actual product experience, and their perspectives on this experience, which they completed following their designs. The second survey (Task 5) consists of student feedback regarding the workshop in general, and was conducted a week after the workshop event.

Table 1. Workshop tasks and the learning methodology applied.

\begin{tabular}{llll}
\hline & \multicolumn{1}{c}{ Tasks } & \multicolumn{1}{c}{ Learning methodology } & Duration \\
\hline 1 & Rediscovering the studio & Observation/reflection, role-play/simulation & 45 minutes \\
2 & 3D experience of design process & Project-based & 6 hours \\
3 & Product experience & Role-play/simulation, reflection & 1 hour \\
4 & Students reflect on product experience & Reflection, survey & 15 minutes \\
5 & Students reflect on workshop & Reflection, survey & 20 minutes \\
\hline
\end{tabular}




\section{Task 1: rediscovering the studio}

The aim of the first task was to direct students to perceive and relate to their immediate environment from a new perspective. They were asked to analyse their studio environment for five minutes and write on Post-its, aspects of the studio that they had not noticed before. Immediately afterwards, the comments were read aloud and discussed together. Comments included certain textures, colours, sounds and architectural or interior design features within the studio. This short exercise focused the students' attention on their surroundings rather than on 'mind stuff'; reminding them that accurately observing their environment is a fundamental requirement for their disciplines.

Afterward, a student volunteer was blindfolded and the peers were assigned to walk the student from one corner of the studio to the other without letting her fall or hit the wall. The blindfolded student (through touching and listening to directions) and the guiding students (through giving directions, counting steps, etc.) devised methods to complete this task that compensated for the lack of vision. This experiment also led to a discussion of different ways of experiencing space and its components as well as how we orient to and relate with space; the ways people use some senses while eliminating others in everyday life.

\section{Task 2: the '3D experience' design process}

Following the introductory session, students were given a full-day assignment. They were asked to design and produce a full-scale product that they and users could experience, exploring the aforementioned issues regarding the person-environment relationship. The project's main intention was to increase participants' inclusive design awareness.

This task's goal was largely determined by the students, and there was no precedent they could turn to because the product's main function was the user experience. In that respect, students were strictly guided that the intention of the project was not to design a product for a differently abled person but to reveal specific qualities of the person-environment encounter that would include (or exclude) the user through his or her engagement with the design. The work could be experienced internally or externally; as such, students would also decide upon the scale. The work could be mobile, allowing it to be carried, or it could be installed as a part of the department's exterior or interior space. The only limitations were that the students had to produce the work themselves, and that the projects could extend to a maximum of three metres in any direction. However, some projects went beyond this limitation by incorporating the built environment, which was encouraged. Students were also required to submit a poster reflecting their design intention.

A sheet consisting of material suggestions (such as cardboard, tape, textile) were handed out to students before the workshop; which they brought with them. However, since the product creation occurred during the workshop event, students supported the event with additional materials that they acquired for their specific designs.

In groups of five to seven, students presented initial ideas through sketches and text. The workshop leader and studio instructors gave immediate feedback after one hour of student brainstorming, and then students were on their own. Despite limited time and material resources, students became fully engaged in the design and production processes, sharing the workload and responsibilities with their teammates. Instructor guidance supported the process, but for the most part, the group had to find their own solutions to problems encountered. Problems usually centred around expressing a certain conceptual idea, the location of the work, the workmanship or structural stability. The lively workshop area was visited by other architecture students and instructors, as well as those from other departments and the university press. The workshop process led to novel, creative and unique outcomes. Photographs pertaining to the process are presented in the next section, along with photos of the final products. 


\section{Task 3: product experience}

Here, we focus on an analysis of the works in terms of the quality of the experience; we note that design unity, use of materials, organisational and three-dimensional principles, structural stability and workmanship were all aspects considered within the design education context.

The products differed in terms of scale, their focus on sensory abilities and whether having a predominantly cognitive/psychomotor or affective intention through design. After completing the design process, students were asked to write about their project, with a focus on their main intention and conceptual ideas. These texts provided valuable insights on how students evaluated their own projects. The students also titled their projects.

The first group called their project 'Life Circle'. It consisted of a series of large cardboard compartments aligned in a circle. In each compartment, the participant would try to perform various activities, such as opening a window or reaching for a pen, while their movements were constrained by different obstructions. Through these activities, the participant became aware of the bodily movements of reaching, bending, seeing/not seeing, turning, etc., and of how the position and availability of certain physical features enabled/disabled them. The intention was to draw attention to the difficulties of not using inclusive design, which affects not only differently abled people, but everyone. Since the project was installed in a pedestrian area on the university campus, it attracted passersby, who then participated in the exercise (Figure 1).

The second project was called 'Freedom'. The group introduced the idea of flying and that everybody was 'free' and equal, having similar experiences in the air. They worked to demonstrate this through simulating a flying experience utilising the existing university environment. Using a pole in the campus's amphitheatre as an anchor, the students placed two safety belts made of rope, bubble wrap and mosquito net around the body of a participant. The ends of the safety belts were kept tight around the pole by a group member while the participant leaned out from one of the stairs with arms open and eyes closed. The intention was to create a platform where everybody, regardless of their differences, could enjoy and be thrilled by the experience of diving into emptiness (Figure 2).
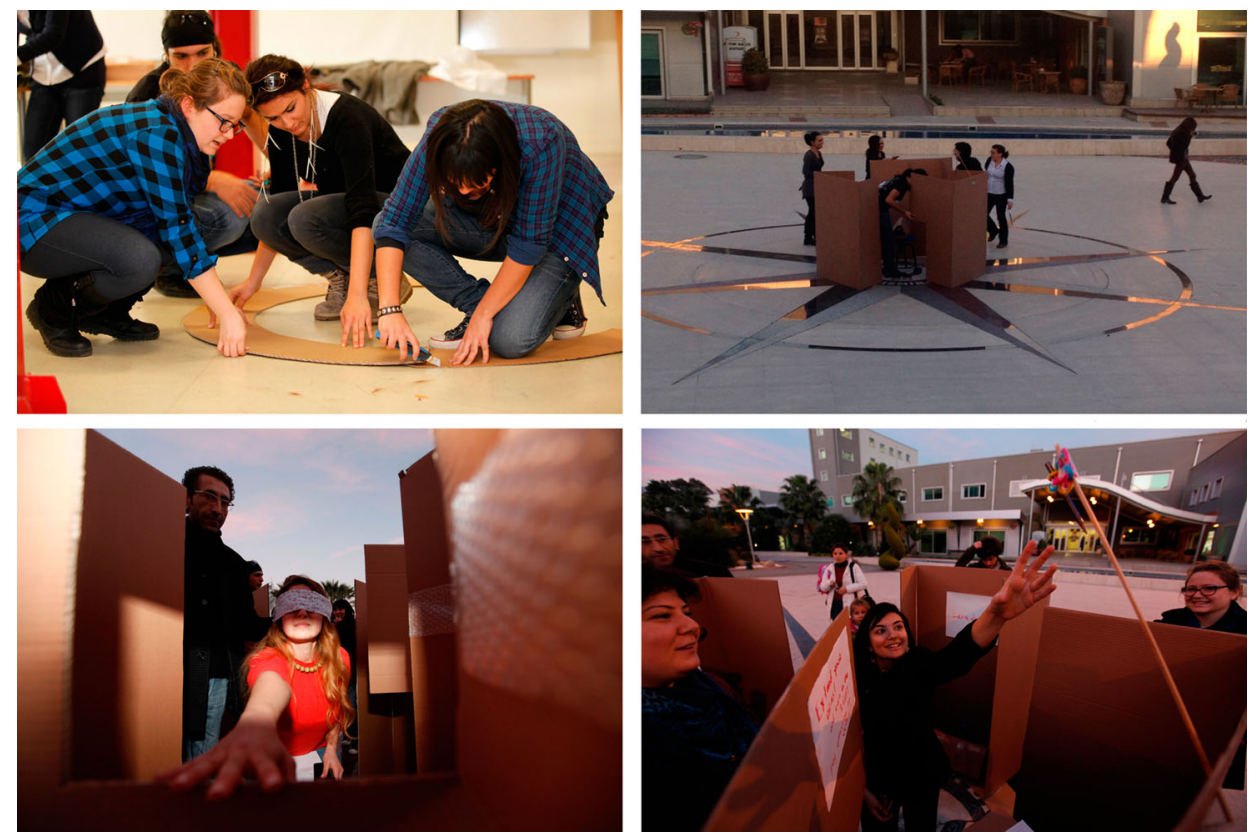

Figure 1. 'Life Circle' (Image courtesy of authors, 2013). 

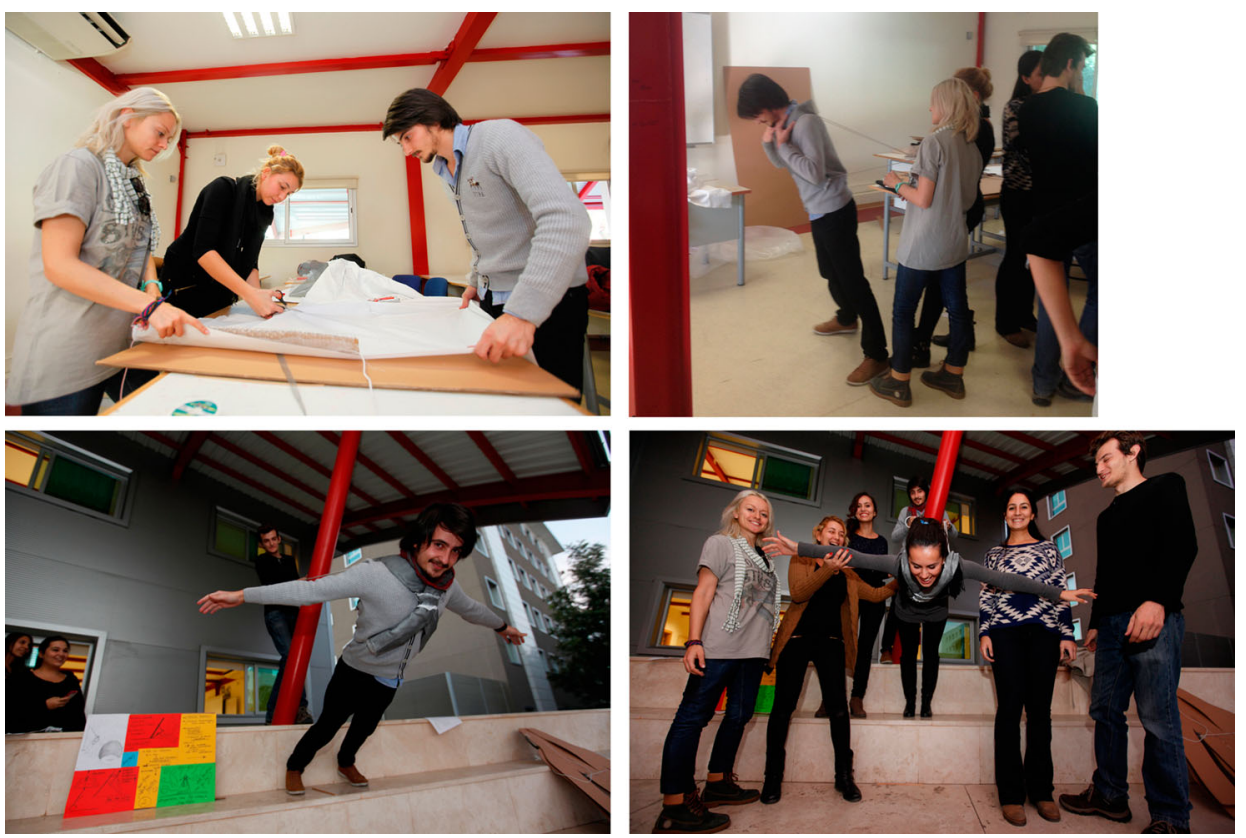

Figure 2. 'Freedom' (Image courtesy of authors, 2013).

The third project was called 'A Box of Experience'. This group offered different experiences to participants using 'the box'. It was constructed of cardboard shot through with thin wooden sticks, which formed a 3D labyrinth inside. The participant would try to reach the end of the box with his or her arm, passing along the sharp points of the sticks that formed the edges/contours of the interior 'void'.
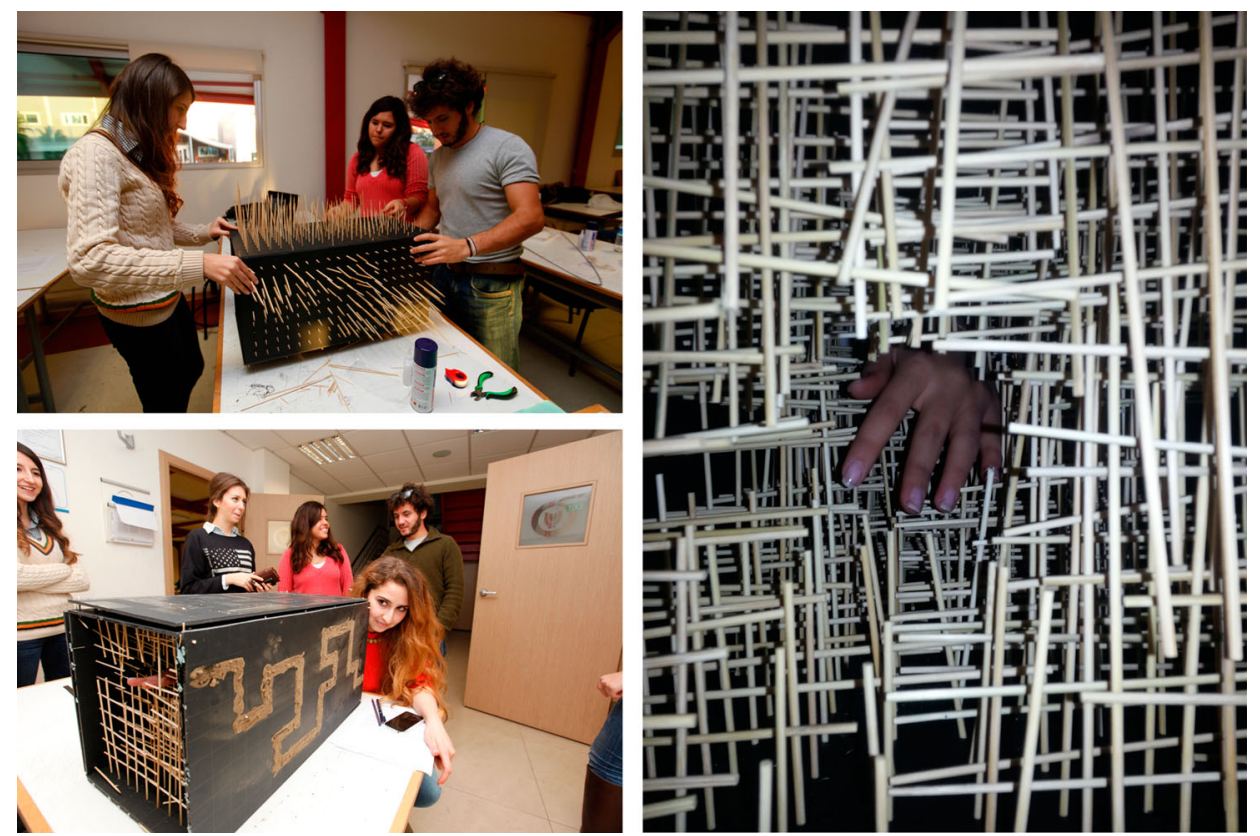

Figure 3. 'A Box of Experience' (Image courtesy of authors, 2013). 
The participant experienced different feelings on different parts of the arm because some parts of the void were easier to pass through than others as the arm became thicker. Participants also experienced the limitations and capabilities of manoeuvring by arm only. The project invited the participant to explore the box using only his or her sense of touch through hand and arm movements (Figure 3).

The fourth project was called 'Two Birds with One Stone'. The project team aimed to discuss the relationship between users and objects in the context of accessibility. Although people may have different barriers, either permanent or temporary, they may encounter the same problems when performing certain activities. For example, climbing stairs is difficult for both a blind person and a pregnant woman. This project thus enabled visitors to gain an awareness of such a situation. The team utilised the existing edge of the campus's amphitheatre stairs and constructed a banister there with cardboard tubes. Participants then wore a blindfold and/or a fake belly to test the work. First, the blindfold and/or the fake belly were fastened on the participant's body and then he or she was asked to climb up and down the stairs. At the end of the activity, the team talked with the participant about the experience. This project offered the opportunity to test accessibility in daily life (Figure 4).

The fifth project was called 'Justouch'. It focused on the sense of touch and aimed to evaluate how we would understand our physical environment if we were only able to use our sense of touch. The team set out different materials (e.g. sand, sugar, stone) on a testing table and used an attached hood to cover the
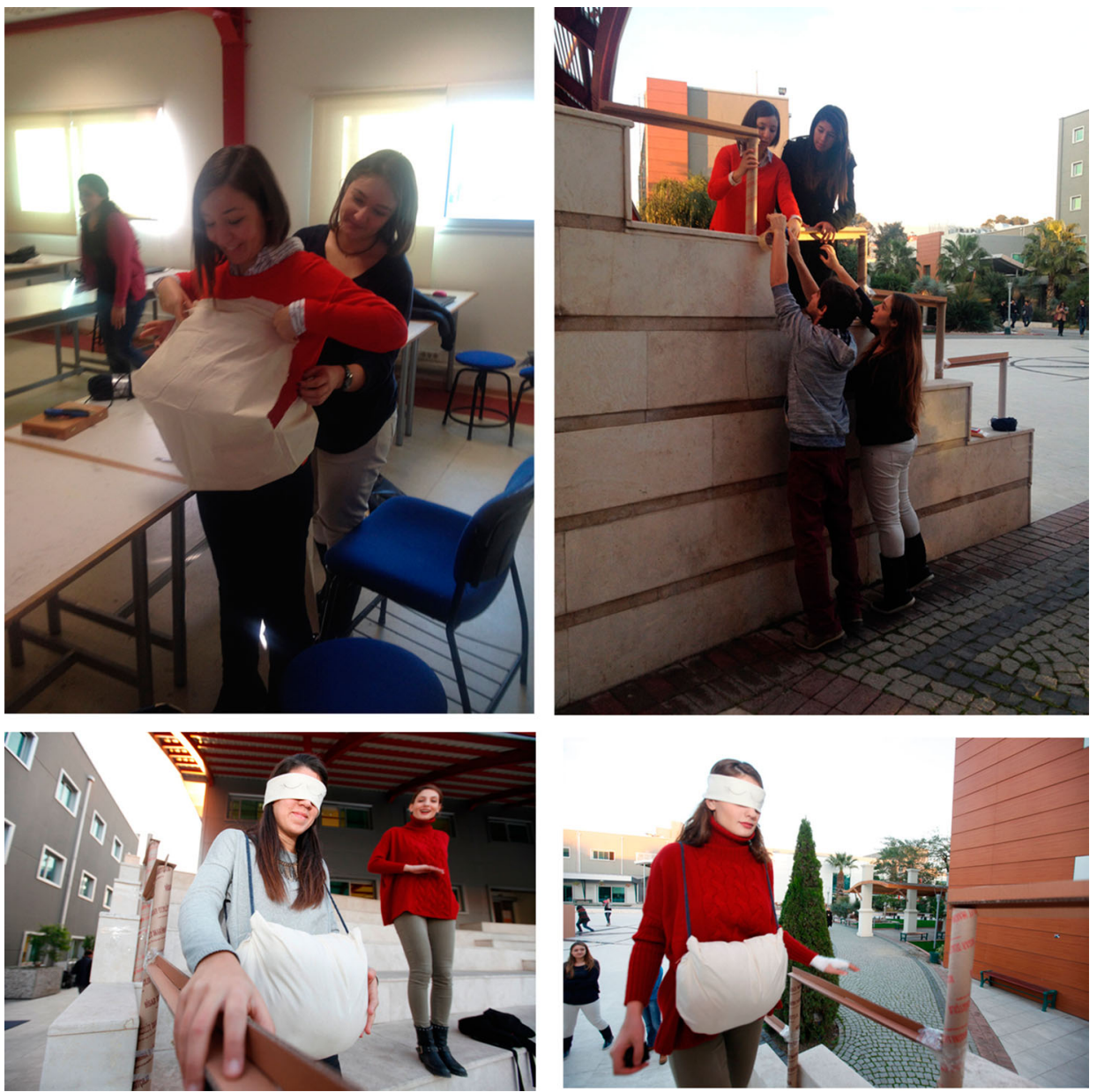

Figure 4. 'Two Birds with One Stone' (Image courtesy of authors, 2013). 

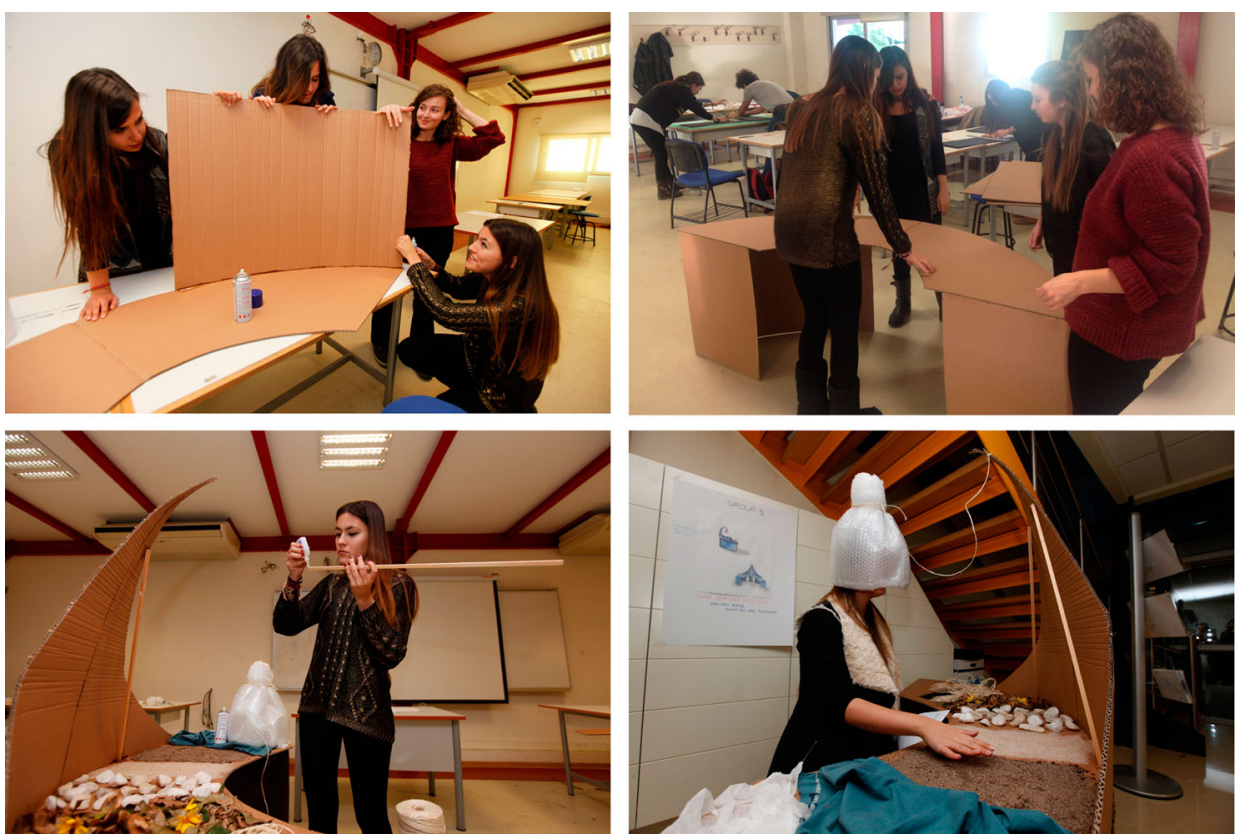

Figure 5. 'Justouch' (Image courtesy of authors, 2013).

participant's face. During testing, the participant tried to identify the material by touching it. In this project, the group emphasised the link between the touch and sight in everyday life (Figure 5).

The sixth group named their project 'Black Tunnel'. The group utilised existing studio panels on two sides to create a tunnel with various obstacles in it made from cardboard, paper, textiles, etc. The objects were placed where they would come into contact with the participant's hands, feet, body and face. The participant was to walk through the path with her eyes covered, meeting these unexpected obstacles along the way. Different obstacles encountered by different parts of the body had varying effects on the person. For example, while the feet were less sensitive to objects due to the participants' shoes, the face was very vulnerable. With this tunnel experience, the group's intention was to develop empathy between the participant and those who encountered similar obstacles in their everyday lives (Figure 6).

The seventh project was called 'Black Box'. This project was composed of a simple black cardboard box with two holes cut at different angles, giving the impression that they provided visual access to the same plane. However, when the participant looked through the holes (one after another), she saw different colours. Actually, the students constructed two coloured planes of red and green, which could not be perceived from the outside. The intention of this project was to show that even when people look at the same area, they may see different things. The work aimed to demonstrate that we should be aware that what we see may not be similar to what others see, and that we should be attuned to other people's views, perceptions and experiences, both mentally and physically (Figure 7).

The eighth project was called 'Taste of Touch'. The intention of this work was to upgrade the existing interior environment three dimensionally through visual and tactile elements. Students established a coding system using materials such as wooden sticks, fishing line and transparent tape, which were perceived as the participant walked along a department corridor. In that respect, students utilised the existing qualities of the space. The participant would understand the locations of doors, stairs, ramps, openings, protrusions, etc. by the accompanying materials on the walls and ceiling, such as different textures, frequency of the objects, slope of the elements, addition of textiles. 

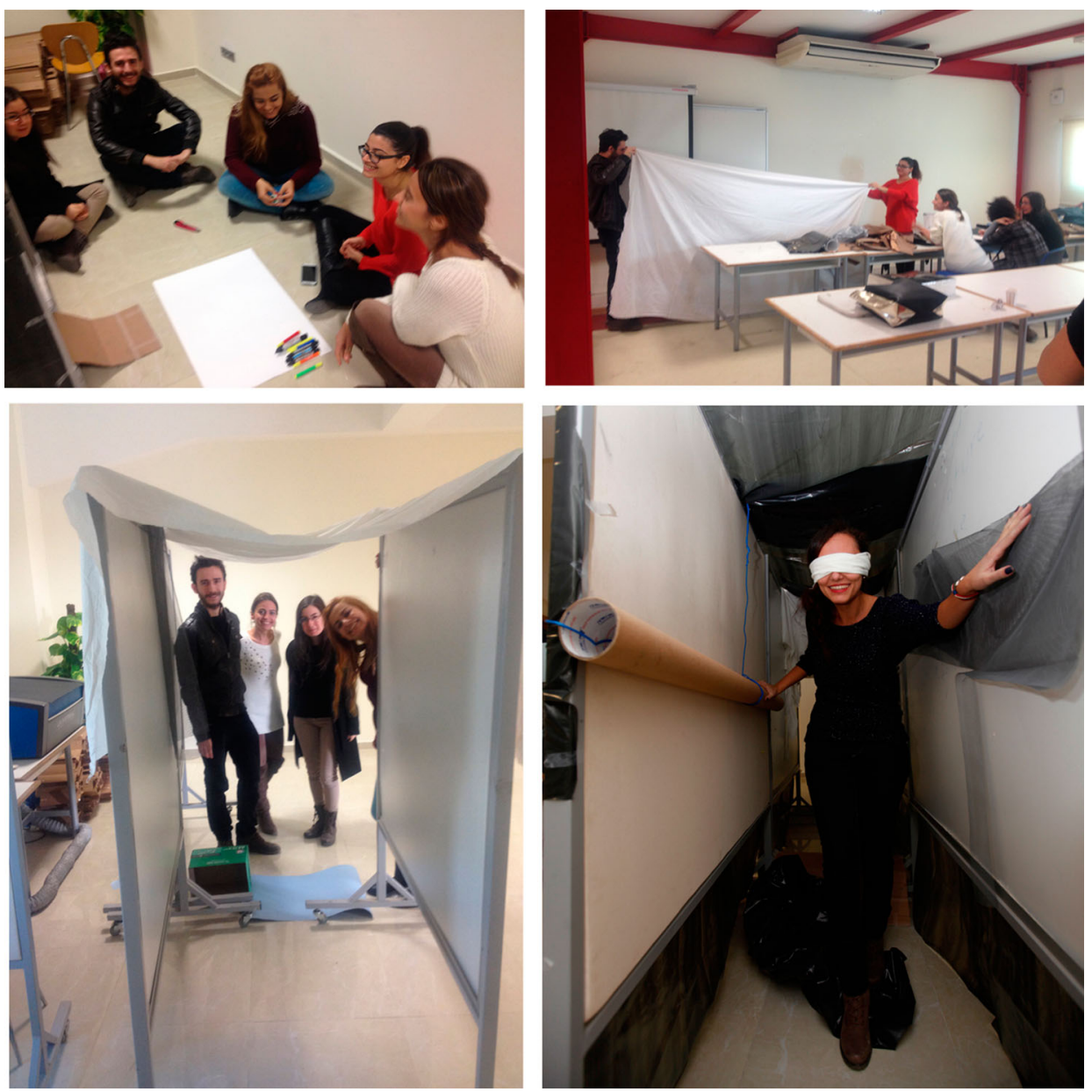

Figure 6. 'Black Tunnel' (Image courtesy of authors, 2013).

Therefore, the project highlighted significant architectural/interior design features of the space which we usually pass by unnoticed (Figure 8 ).

\section{Task 4: students' reflections on the product experience}

Immediately following the workshop process and during the product experience, students had an opportunity to assess the quality of the products. This opportunity allowed students to express their views as 'users' of other works, in addition to being 'designers'. The survey was conducted as soon as students completed the 3D experiences, thus it encouraged them to provide instant reflections on their actions. The main educational objective was to reflect on the outcomes and their experiences from the perspective of the workshop's initial intention: inclusive design awareness. Analysing the survey results, we explored the predominant themes that emerged in how the product experience affected student learning. Thirty-three students completed the survey.

The first two questions explored students' general evaluation of the products (their own and others' products). Table 2 represents the findings.

The findings indicate that student believed the product experience increased their awareness. They also reflect a positive experience regarding the products. 

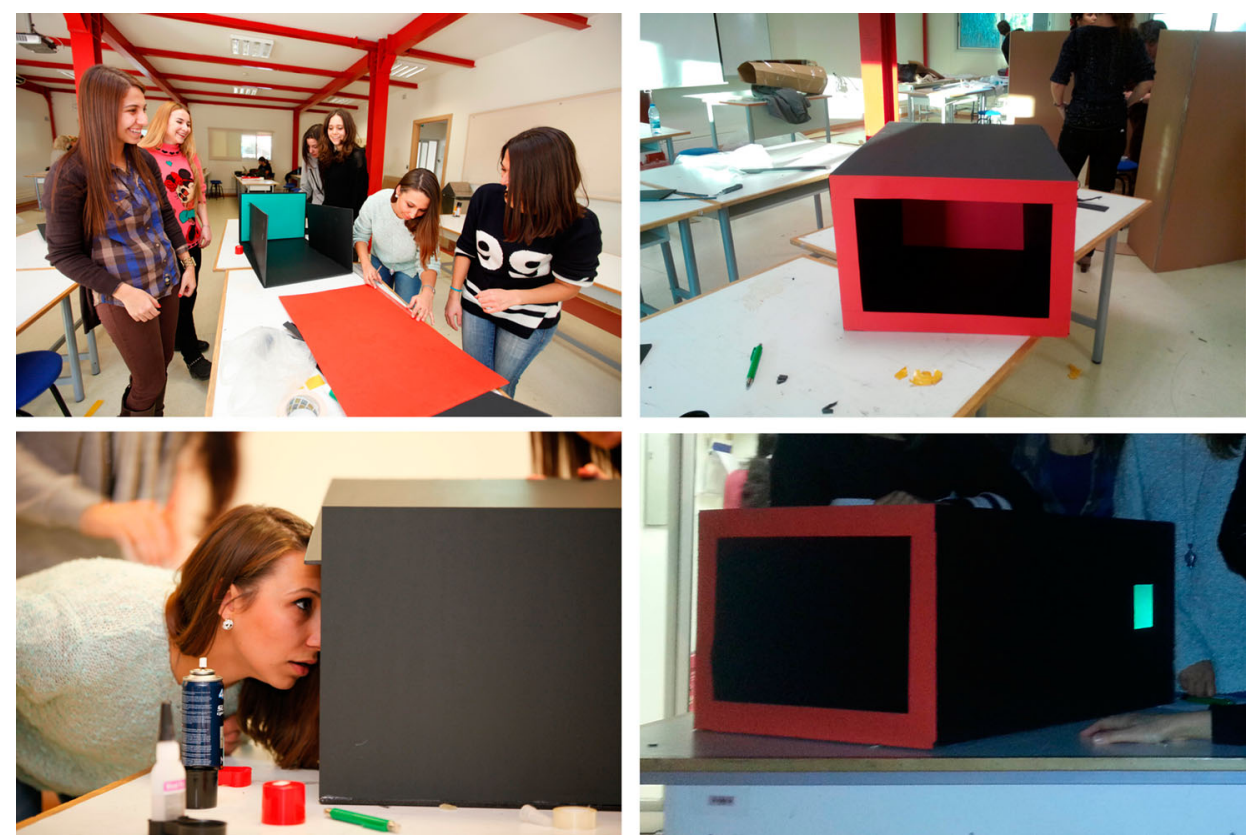

Figure 7. 'Black Box' (Image courtesy of authors, 2013).

The second set of questions asked students to choose their favourite product (other than what they created). Table 3 shows the findings.

An open-ended question followed the above questions, asking students to comment briefly on the product that they chose. In one to three sentences we asked students to comment on why they thought the experience of the chosen product was positive. We analysed students' written reflections by emergent themes (Boyatzis 1998) and characterised these reflections as data-driven. For this study, we coded the results with reference to Boyatzis (1998) study. Twenty-one of 33 students provided comments.

The first emergent theme was the affective/emotional response resulting from the experience. Fifty-seven per cent of students (12 people) used the word 'feel' or 'feeling' regarding an aspect of their experience. For them, the projects either revealed what the disabled felt, or what the able-bodied did not see/feel in everyday life before. Products were termed as 'effective', 'good', 'useful' or 'successful' in increasing one's awareness, or allowed one to feel 'different', 'funny' or 'frightened'.

The second theme, directly associated with the first one, was about the physical/bodily response of the experience (seven people, 33\%). When reflecting on the project quality, in addition to the emotional response elicited by the project, students often acknowledged the bodily sensations that resulted. Students often noted how those two responses aided them in going beyond mere knowledge of the subject to reach an understanding of it. ${ }^{1}$

This workshop made me see something more clearly: everybody knows that 'design for everyone' is important, but after this work, for sure everybody understood and felt it by touching, seeing and walking inside the project. Now I am sure that it helped me to see the difference. (Project 1, 'Life Circle')

If I were a blind person, the first thing I would want to feel is confidence because every part of my body [would feel] like I was in space. But this design provides confidence to find my way so it's really good. (Project 3, 'A Box of Experience')

The third theme that emerged related to the quality of the product regarding the creative aspect. Students (six people, 28\%) appreciated the products' 'uniqueness' and 'creativity', focusing on how they were able to bring about awareness with a 'good', 'interesting' or 'different' idea. 

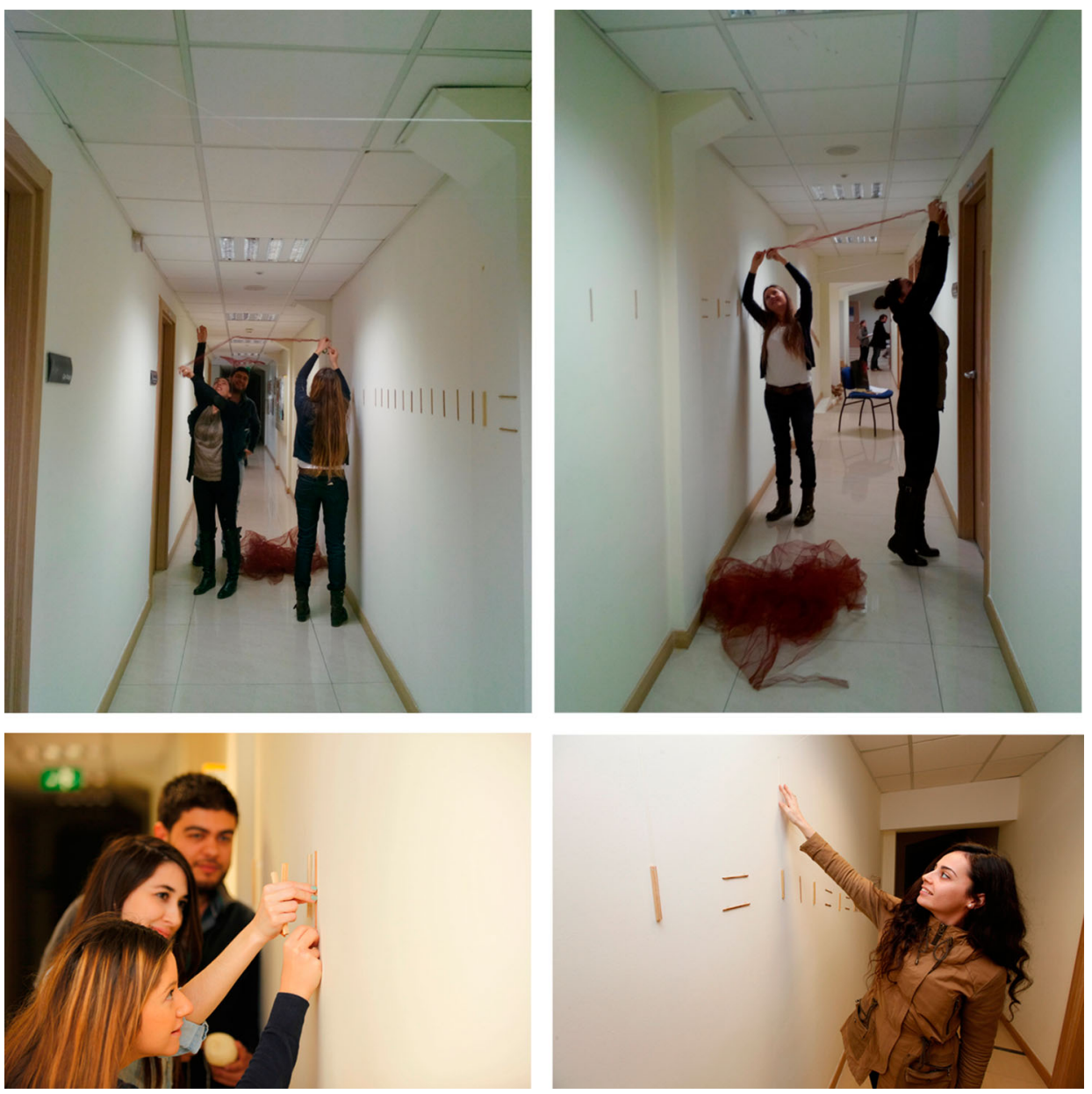

Figure 8. 'Taste of Touch' (Image courtesy of authors, 2013).

Twenty-four per cent of students (five people) noted that all products were successful in their intent and were creative and successful in meeting the basic requirements of the workshop.

After the evaluation process, the products were displayed until the end of the week and the conference/workshop event was discussed in several local newspapers and one national newspaper.

\section{Task 5: students' reflections on the workshop}

To investigate students' perceptions of their learning experience, we conducted another survey a week after the workshop. A written questionnaire was given to students to voluntarily complete

Table 2. Student assessment of the product experience.

\begin{tabular}{|c|c|c|}
\hline Questions & $\begin{array}{l}\text { No. of stud. } \\
\text { answered }\end{array}$ & Mean \\
\hline $\begin{array}{l}1 \text { - To what extent did the product experience lead to increased awareness with respect to some } \\
\text { aspect of human diversity/inclusivity/inclusive design? } \\
1=\text { not at all, } 2 \text { = very little, } 3=\text { moderately, } 4=\text { greatly, } 5=\text { extremely }\end{array}$ & 33 & 4.09 \\
\hline $\begin{array}{l}2 \text { - Rate the overall quality of the product experience } \\
1=\text { poor, } 2=\text { fair, } 3=\text { neutral, } 4=\text { good, } 5=\text { excellent }\end{array}$ & 33 & 4.22 \\
\hline
\end{tabular}


Table 3. Students' favourite products.

\begin{tabular}{llcc}
\hline Rank & Project name/number & No. of stud. (out of 30) & $\%$ of stud. \\
\hline 1 & 2/Freedom & 9 & 31 \\
2 & 6/Black Tunnel & 8 & 28 \\
3 & 1/Life Circle & 4 & 14 \\
4 & 3/A Box of Experience & 4 & 14 \\
5 & 4/Two Birds with One Stone & 3 & 10 \\
6 & 8/Taste of Touch & 1 & 3 \\
\hline
\end{tabular}

in 20 minutes. Students were clearly informed that the survey was for education/research purposes and for improving future events. They were not required to write their names on the forms. Thirtythree students completed the survey.

To explore the research question, the students were asked four questions, consisting of two closed-ended and two open-ended questions. The first two questions were rated on a five-point scale; Table 4 summarises those findings.

The open-ended questions asked students to briefly comment on their positive and negative views of the workshop's content and format. The students were directed by these questions, so that their reflections would provide the development of further workshop experiences both in terms of process, subject and students' expectations. We thematically coded students' answers (between one and four sentences) and placed them into three major themes (Boyatzis 1998).

The highest-ranked positive aspect of the workshop, related to its main objective, that is, the learning outcome: $67 \%$ of students (22 out of 33 people) noted an increase in their awareness of inclusivity. Students commented that because they noticed aspects of the environment that they previously had not, they were able to see it from a new perspective, which increased empathic understanding. Learning through experience was noted to be a very distinct and educative quality. Students elaborated their learning experiences as follows:

We learned about working as a group and doing something important to make people aware of 'living with a disability'.

We attempted to increase awareness of the environment without categorizing people.

I learned to look from a perspective that I had not before. First of all, I learned to be aware of lots of problems that can be encountered in everyday life that I had not been aware of or thought about before. It was a beautiful experience.

We realized design is a requirement for everyone; and that whether with or without a disability, everyone has the right to live the same life.

We did not only [aim to feel] like a person with a disability, we aimed to surpass all limitations and empathize with others.

The second-ranked theme that emerged was the enjoyable quality of the process. Fifteen, out of 33 people (45\%) commented that they really enjoyed the workshop, had a 'lot of fun' and were with motivation and energy:

I got excited when I heard about the workshop. This workshop experience was beyond my expectations. It was very enjoyable.

The third positive aspect students noted was related to the high quality of the products as an outcome of the process (10 people, $30 \%)$. Students stated that they were able to put into practice and

Table 4. Student assessment of the workshop.

\begin{tabular}{|c|c|c|}
\hline Questions & $\begin{array}{l}\text { No. of stud. } \\
\text { answered }\end{array}$ & Mean \\
\hline $\begin{array}{l}1 \text { - To what extent did your attendance at the workshop lead to increased awareness with respect to } \\
\text { some aspect of human diversity/inclusivity/inclusive design? } \\
1=\text { not at all, } 2 \text { = very little, } 3=\text { moderately, } 4=\text { greatly, } 5=\text { extremely }\end{array}$ & 33 & 4.03 \\
\hline $\begin{array}{l}2 \text { - Rate the overall quality of the workshop experience } \\
1=\text { poor, } 2=\text { fair, } 3=\text { neutral, } 4=\text { good, } 5=\text { excellent }\end{array}$ & 33 & 4.03 \\
\hline
\end{tabular}


experience what they had learned in theory, develop their creative abilities, work cooperatively in groups and succeed in producing good-quality products in a limited and concentrated time.

The following student comment demonstrates all three positive aspects of the workshop:

The subject interested me before, but I never imagined I would have this much fun! With the instructors and all the students, within the given time and with high concentration, we produced beautiful work. I believe my awareness has increased as a result.

Discussing the negative aspects of the workshop, the most outstanding problem students faced was limited production time. Fourteen people (42\%) commented that they could have constructed higher-quality products if they had had more time. The second problem students faced was related to the product exhibition, trial and evaluation (9 people, $27 \%$,). Students wished for more time to experience the products of their peers and wanted more feedback from the instructors. They also commented that the exhibition of the products was inadequate because the installations located outside had to be moved inside due to forecast rain. Students also felt that the exhibition time should have been longer. The third emerging problem was felt to be constraints based on the availability of material resources (eight people, 24\%). Preparing the materials before the workshop rather than trying to find some of them during the workshop seemed to put further limitations on time, and some students noted that the financial burden of the materials was too much. Four students (12\%) had no negative comments.

The positive feedback from students revealed that 'enjoying the process' is a very important component of a perceived learning experience. The students acknowledged that the process was joyful and that they engaged and participated in it collaboratively. Students' suggestions to extend the workshop to two days to allow more time for the production process, the product experience and instructor/student feedback, and for gathering material resources was also very valuable. All feedback could be incorporated into future workshops to improve such learning experiences.

\section{Conclusion and suggestions}

The workshop was successful because it allowed students to expand their vision about the userenvironment relationship from the human-factors perspective as they engaged with the work hands-on. As such, a 'connected knowing' enabled the dissolution of boundaries between themselves and the user (Ballard 1997). Without making distinctions between 'us' and 'them', 'abled' and 'disabled' or 'user' and 'designer', the project provided a creative framework through which to approach the idea of inclusivity by design. The workshop was thus both a platform for research and knowledge-making, and a medium for authentic production, in that students were able to make meaningful connections among their current/existing lived experience and 'newer' views, understandings and experiences within a real-world context (Stein, Isaacs, and Andrews 2006).

The students' created products and their assessments of the product experience/workshop in general revealed significant ways to embody empathic strategies in inclusive design education. Initially, the results suggest that student participation, involvement and creativity greatly enhance their positive perspectives about the learning process. The enjoyment of the actual process seems to be a determinant of how students' evaluate the learning event. Moreover, the multiple modes of participating in the event and the co-creation of knowledge through students' own initiative are effective in and supportive of the learning process, particularly around enhancing students' attitudes and affective outlook towards the subject. The students utilised their hearts, bodies and minds while engaging in the project at different levels, and the impacts of their creations on the environment and others were directly visible and experienced.

Students' reflections on their positive interactions with the instructors during the workshop process, as well as their need for further interaction and reflection at the end of the project, suggest the significant role of instructors in student development. Bulman, Lathlean, and Gobbi (2014) indicate that for reflective education, the educator's role is that of a 'skilled facilitator'. In that atmosphere, 
instructor-student status differences decrease and students and instructors work and learn together through dialogue and the 'opening up' of experiences. The facilitator 'guides and enables people on their learning journey, rather than leaving them to it or didactically telling them what to do' (Bulman, Lathlean, and Gobbi 2014, 1231).

The actual experience of the workshop by students and instructors had further influences on the learning journey from the instructors' point of view. The highly imaginative and experiential products created by the students encouraged the instructors to intensify single-day workshops within the curriculum, either as single-day events open to all levels, or confined within design studio courses. The student comments on lack of time and material resources has been partly overcome by introducing the students to the contents and expectations a few days prior to the actual event, and organising the day so that adequate time for instructor feedback is always available at the end. Meanwhile, a modified and adapted version of this assignment has been integrated within a Human Factors/Ergonomics course in the IAED department of another university. This course is a predominantly lecture course which also includes explorations for adopting empathic and learner-centred methodologies (Altay 2014; Altay and Demirkan 2014), achieving very positive results. As a human-centred design approach suggested by Giacomin (2014), the effects of the workshop transcended our prior imagination, providing innovative and intuitive engagements with the physical/learning environments.

The conference and workshop events suggest further considerations within the design education curriculum. First, a multitude of learner-centred methods that support one another helps students understand and engage with the learning material at different levels. Moreover, empathic research and design strategies (which allow students to re-discover themselves as well as learn possible ways of how others relate to the world) support inclusive design awareness and encourage reflection on design outcomes. As our results show, when dealing with the human-environment relationship, while bodily engagement and psychomotor learning seem to be predominantly experienced by students, students also acquire learning in the affective domain. Thus, students reflected not only on how they related differently to aspects of the products, but also how this reflection influenced their attitudes, particularly considering the difficulties of differently abled people in everyday life. Finally, students valued and enjoyed their work being experienced by their peers and instructors. In any disciplinary context, for high student satisfaction and positive experience, adequate time and emphasis should be given to the evaluation and presentation processes, and the processes should be supported with exhibitions of sufficient length aimed at a (at least in the case of inclusive design awareness) wide audience. This workshop was an attempt to bring the issue of inclusivity into the core of the design profession's identity and practice, something much needed in the Turkish context.

\section{Note}

1. Excerpts of students' reflections have been edited for clarity.

\section{Notes on contributor}

Burçak Altay is currently an instructor in the Interior Architecture and Environmental Design Department at Bilkent University where she teaches Design Studio and Human Factors courses. She earned her B.Arch. from Middle East Technical University, M.F.A. and Ph.D. from Bilkent University. She previously worked as a programmer, designer and technical coordinator at Skidmore Owings and Merrill architectural firm in New York. Her research areas include architectural ethics, professional practice, project planning and programming, creativity and empathic design education.

Gülnur Ballice currently works at Yaşar University's, Faculty of Architecture, in the Department of Interior Architecture and Environmental Design, where she held the position of department head between 2006 and 2013. She earned her B.Arch. from Dokuz Eylül University, M. Arch. from Middle East Technical University and Ph.D. from Dokuz Eylül University. She also worked in architectural firms between 1991-2005. Her main research topics include 
urban transformation/renewal, urban identity, creative housing approaches, the history and theory of modern architecture/interior architecture/design, housing and culture.

Ebru Bengisu is currently a research assistant in the Department of Interior Architecture and Environmental Design Department at Yaşar University. She received her B.A. from Bilkent University's Interior Architecture and Environmental Design Department. Her research areas include environmental psychology, housing and research methods in design studies.

Sevinç Alkan-Korkmaz is currently a Ph.D. student at the Department of Architecture, Dokuz Eylül University, where she is studying the practice of copying in contemporary architecture. She also worked as a researcher at Yaşar University, Department of Interior Architecture and Environmental Design, between 2009-2015. She earned her B. Arch. from Uludağ University and M.Sc. from Dokuz Eylül University.

Eda Paykoç is currently a research assistant at Yaşar University's Department of Interior Architecture and Environmental Design, and a Ph.D. candidate in İzmir Institute of Technology, Department of Architecture. She received her B.A and M.A. from Bilkent University's Department of Interior Architecture and Environmental Design. Her research areas include environmental psychology, the theory of modern architecture and social theories in current issues in architecture.

\section{References}

Aditomo, A., P. Goodyear, A. Bliuc, and R. Ellis. 2013. "Inquiry-Based Learning in Higher Education: Principal Forms, Educational Objectives, and Disciplinary Variations." Studies in Higher Education 38 (9): 1239-1258.

Afacan, Y. 2008. "Designing for an Aging Population: Residential Preferences of the Turkish Elderly to Age in Place." In Designing Inclusive Futures, edited by P. Langdon, P. J. Clarkson, and P. Robinson, 241-252. London: Springer.

Afacan, Y. 2011. "Teaching Universal Design: An Empirical Research in Interior Architecture." Procedia Social and Behavioral Sciences 15: 3185-3192.

Altay, B. 2014. "User-Centered Design Through Learner-Centered Instruction." Teaching in Higher Education 18 (2): 138-155. doi:10.1080/13562517.2013.827646.

Altay, B., and H. Demirkan. 2014. "Inclusive Design: Developing Students' Knowledge and Attitude Through Empathic Modeling." International Journal of Inclusive Education 19 (2): 196-217. doi:10.1080/13603116.2013. 764933.

Ballard, K. 1997. "Reaching Disability and Inclusive Education: Participation, Construction and Interpretation." International Journal of Inclusive Education 1 (3): 243-256.

Başbakanlık, T. C. 2005. Kamu Yönetiminde Yeniden Yapılanma 9- Sosyal Güvenlik Reformu: Sorunlar ve Çözüm Önerileri, 35. Ankara: Başbakanlık Basımevi.

Bonwell, C. C., and T. E. Sutherland. 1996. “The Active Learning Continuum: Choosing Activities to Engage Students in the Classroom." New Directions for Teaching and Learning 67 (2): 3-16.

Boyatzis, Richard E. 1998. Transforming Qualitative Information: Thematic Analysis and Code Development. Thousand Oaks, CA: Sage.

Buchanan, R. 2001. "Human Dignity and Human Rights: Thoughts on the Principles of Human-Centered Design." Design Issues 17 (3): 35-39.

Bulman, C., J. Lathlean, and M. Gobbi. 2014. "The Process of Teaching and Learning about Reflection: Research Insights from Professional Nurse Education.” Studies in Higher Education 39 (7): 1219-1236.

Committee on the Rehabilitation and Integration of People with Disabilities. 2001. Resolution ResAP (2001)1 on the Introduction of the Principles of Universal Design into the Curricula of all Occupations Working on the Built Environment. Strasbourg: Council of Europe. Accessed December 14, 2014. http://www.coe.int/t/e/social_ cohesion/soc-sp/ResAP\%282001\%29E\%20.pdf.

Cross, N. 1982. “Designerly Ways of Knowing.” Design Studies 3: 221-227.

Cross, N. 2001. "Designerly Ways of Knowing: Design Discipline Versus Design Science.” Design Issues 17 (3): $49-55$.

Dankl, K. 2013. "Style, Strategy and Temporality: How to Write and Inclusive Design Brief?" The Design Journal 16 (2): 159-174.

Dostoğlu, N., E. Şahin, and Y. Taneli. 2009. Evrensel Tasarım: Tanımlar, Hedefler, İlkeler, Mimarlık, 347. Accessed November 23, 2015. http://www.mimarlikdergisi.com/index.cfm?sayfa=mimarlik\&DergiSayi=361\&RecID=2062.

Giacomin, J. 2014. "What Is Human Centred Design?” The Design Journal 17 (4): 606-623.

Heyward, P. 2010. "Emotional Engagement Through Drama: Strategies to Assist Learning Through Role-play." International Journal of Teaching and Learning in Higher Education 22 (2): 197-203.

Jones, J. C. 1992. Design Methods. New York: Van Nostrand Reinhold.

Kahu, E. R. 2013. "Framing Student Engagement in Higher Education.” Studies in Higher Education 38 (5): $758-773$.

Kouprie, M., and F. S. Visser. 2009. “A Framework for Empathy in Design: Stepping Into and Out of User's Life.” Journal of Engineering Design 20 (5): 437-448. 
Kreber, C. 2001. "Learning Experientially Through Case Studies? A Conceptual Analysis." Teaching in Higher Education 6 (2): 217-228.

Lee, N. 2009. "Project Methods as the Vehicle for Learning in Undergraduate Design Education: A Typology." Design Studies 30 (5): 541-560.

Lewis, J. L. 2011. "Student Attitudes Toward Impairment: An Assessment of Passive and Active Learning Methods in Urban Planning Education." Teaching in Higher Education 16 (2): 237-249.

Livingston, K. 2000. "When Architecture Disables: Teaching Undergraduates to Perceive Ableism in the Built Environment.” Teaching Sociology 28 (3): 182-191.

McDonagh, D., and J. Thomas. 2010. "Disability + Relevant Design: Empathic Design Strategies Supporting More Effective New Product Design Outcomes.” The Design Journal 13 (2): 180-198.

McGinley, C., and H. Dong. 2011. "Designing with Information and Empathy: Delivering Human Information to Designers." The Design Journal 14 (2): 187-206.

Mishchenko, E. D. 2008. "Disability." In The Design and Planning Education, Curriculum of Departments, Courses, Projects (Tasarım ve Planlama Eğitiminde "Engellilik" Bölüm Programları, Dersler, Projeler)". Accessed November 23, 2015. http://www.mobbig.org/belge/MOBBIG-29/EvrimMishchenko-Sunu-mobbig29.pdf.

Morrow, R., ed. 2002. Centre for Education and the Built Environment. Building and Sustaining a Learning Environment for Inclusive Design: A Framework for Teaching Inclusive Design Within Built Environment Courses in the UK. Final Report of the Special Interest Group in Inclusive Design for Centre for Education in the Built Environment. UK: Center of Education. Accessed September 16, 2012. http://cebe.cf.ac.uk/learning/sig/inclusive/ full_report.pdf.

National Qualifications Framework for Higher Education in Turkey (NQF-HETR). 2015. Accessed November 23, 2015. http://tyyc.yok.gov.tr/.

Olguntürk, N., and H. Demirkan. 2009. "Ergonomics and Universal Design in Interior Architecture Education." METU Journal of the Faculty of Architecture 26 (2): 123-138. doi:10.4305/METU.JFA.2009.2.7.

Öztül, A. E., C. Girgin, O. Tutal, and M. Ö. Atay. 2011. Herkes için tasarım müfredatı geliştirme çalıstayı sonuç raporu [Design for All Workshop Report]. Anadolu University. Accessed December 15, 2014. http://hertas.anadolu.edu.tr/ calistay_hertas_eskisehir2011_sonucraporu.pdf.

Postma, C. E., E. Zwartkruis-Pelgrim, E. Daemen, and J. Du. 2012. “Challenges of Doing Empathic Design: Experiences from Industry.” International Journal of Design 6 (1): 59-70.

Resmi Gazete [Official journal]. 2010. "Yükseköğretim kurumları engelliler danışma ve koordinasyon yönetmeliği [Regulations for Higher Education Institutions' Disabled Consultation and Coordination].” August 14. no. 27672.

Ryan, M. 2013. “The Pedagogical Balancing Act: Teaching Reflection in Higher Education.” Teaching in Higher Education 18 (2): 144-155.

Schon, Donald. 1983. The Reflective Practitioner. San Francisco, CA: Jossey-Bass.

Stein, S. J., G. Isaacs, and T. Andrews. 2006. "Incorporating Authentic Learning Experiences Within a University Course." Studies in Higher Education 29 (2): 239-258.

Sutherland, A. 2011. "The Role of Theatre and Embodied Knowledge in Addressing Race in South African Higher Education." Studies in Higher Education 38 (5): 728-740.

The Center for Universal Design. 1997. The Principles of Universal Design, Version 2.0. Raleigh: North Carolina State University. Accessed January 14, 2011. http://www.ncsu.edu/www/ncsu/design/sod5/cud/about_ud/ udprinciplestext.htm.

TSI (Turkish Statistical Institute). 2002. Özürlülük Oranı [Disability Rate]. Turkish Statistical Institute. Accessed December 15, 2014. http://www.tuik.gov.tr/PreTablo.do?alt_id=1017.

TSI (Turkish Statistical Institute). 2014. Yillara, yaş grubu ve cinsiyete göre nüfus 1935-2014 [Population Per Year, Age and Gender]. Turkish Statistical Institute. Accessed December 15, 2014. http://www.tuik.gov.tr/UstMenu.do? metod=temelist.

Türel, H. S., E. M. Yiğit, and İ. Altuğ. 2007. "Evaluation of Elderly People's Requirements in Public Open Spaces: A Case Study in Bornova District (İzmir, Turkey).” Building and Environment 42 (5): 2035-2045.

United States Department of Education. 2013. Accessibility and Universal Design. Office of Vocational and Adult Education. Accessed February 24, 2013. http://www2.ed.gov/about/ offices/list/ovae/pi/AdultEd/disaccess.html\#3.

Watchorn, V., H. Larkin, S. Ang, and D. Hitch. 2013. "Strategies and Effectiveness of Teaching Universal Design in a Cross-faculty Setting." Teaching in Higher Education 18 (5): 477-490. 